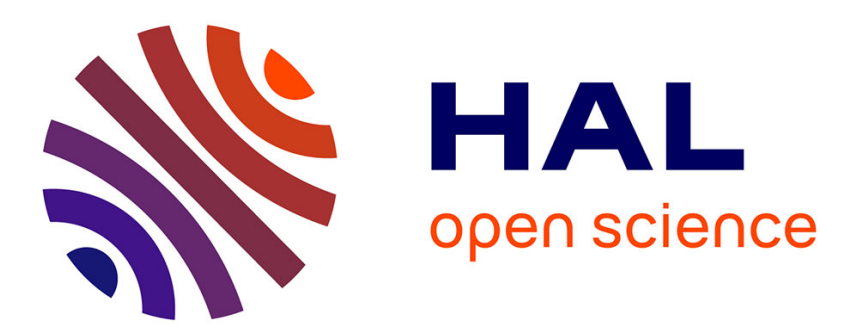

\title{
Oestradiol enhances apoptosis in bovine mammary epithelial cells in vitro
}

Lucile Yart, Laurence Finot, Vanessa Lollivier, Frederic Dessauge

\section{To cite this version:}

Lucile Yart, Laurence Finot, Vanessa Lollivier, Frederic Dessauge. Oestradiol enhances apoptosis in bovine mammary epithelial cells in vitro. Journal of Dairy Research, 2013, 80 (1), pp.113-121. 10.1017/S0022029912000714. hal-01210411

\section{HAL Id: hal-01210411 \\ https://hal.science/hal-01210411}

Submitted on 29 May 2020

HAL is a multi-disciplinary open access archive for the deposit and dissemination of scientific research documents, whether they are published or not. The documents may come from teaching and research institutions in France or abroad, or from public or private research centers.
L'archive ouverte pluridisciplinaire $\mathbf{H A L}$, est destinée au dépôt et à la diffusion de documents scientifiques de niveau recherche, publiés ou non, émanant des établissements d'enseignement et de recherche français ou étrangers, des laboratoires publics ou privés. 


\title{
Oestradiol enhances apoptosis in bovine mammary epithelial cells in vitro
}

\author{
Lucile Yart $^{1,2}$, Laurence Finot ${ }^{1,2}$, Vanessa Lollivier ${ }^{1,2,3}$ and Frederic Dessauge ${ }^{1,2 *}$ \\ ${ }^{1}$ INRA, UMR1348 Pegase, F-35590 Saint-Gilles, France \\ ${ }^{2}$ Agrocampus Ouest, UMR1348 Pegase, F-35590 Rennes, France \\ ${ }^{3}$ Université européenne de Bretagne, France
}

Received 17 August 2012; accepted for publication 8 November 2012; first published online 14 December 2012

\begin{abstract}
Ovarian steroids, oestradiol and progesterone, are required for normal mammary growth at puberty and during pregnancy. They contribute to mammary parenchyma development by stimulating mammary epithelial cell (MEC) proliferation. However several studies demonstrate that oestradiol negatively affects milk production during the declining phase of lactation, but the oestradiol effect on MEC in lactating mammary gland remains unclear. The objective of this study was to investigate the differential effect of oestradiol on bovine MECs mimicking two physiological statuses: active and early apoptotic MECs. We demonstrated that oestradiol has a major effect on early apoptotic MECs and might accelerate MEC apoptosis by activation of caspases rather than by inducing apoptosis in active MECs. Early apoptotic MECs could be compared with senescent cells in the late-lactation mammary gland. These results suggest that the negative effect of oestradiol on milk production during the declining phase of lactation would be due to an enhancement of apoptotic processes in MECs.
\end{abstract}

Keywords: Oestradiol, mammary epithelial cell, apoptosis, cow, MAC-T cell.

In ruminants, the development of the mammary gland occurs during four major stages of life: pre-puberty, postpuberty, gestation and lactation. Before and after puberty, mammary development is strongly related to ovarian activity, which stimulates mammary growth (Aker, 2002). After the first sexual cycle, oestrogens allow development of the mammary gland duct system. From the 5th month of gestation, the lobulo-alveolar system develops, and mammary acini length and number increase (Tucker, 2000). Mammary epithelial cells (MECs) are responsible for the production of milk within the mammary gland (Forsyth, 1986; Tucker, 2000). Their number and activity are controlled during the different developmental cycles of the mammary gland and are under the influence of the animal's hormonal status. Mammogenic hormones, such as the oestrogens, stimulate MEC proliferation and induce maturation of mammary acini for milk production (Clarke, 2000). Experiments in vivo investigating the suppression of ovarian secretions in heifers and prepubertal goats (Berry et al. 2003a; Yart et al. 2012a) and experiments in vitro using

*For correspondence; e-mail: frederic.dessauge@rennes.inra.fr
MAC-T cells (Woodward et al. 1993) indicate that oestradiol $\left(E_{2}\right)$ is essential for mammary parenchyma development and that $E_{2}$ stimulates MEC proliferation. Oestrogens produced by the feto-placental unit contribute to the development of the alveolar tissue (Desjardins et al. 1968), and their secretion increases progressively during gestation and decreases abruptly at parturition (Patel et al. 1999). During lactation, various studies have shown opposite effects of $\mathrm{E}_{2}$ on mammary cells.

Forty years ago, Mollett et al. (1976) performed experiments involving injections of sexual steroids (oestradiol and progesterone) into lactating cows. These authors showed that the steroids had negative effects on the production of milk and modified its composition. Athie et al. (1996) specifically studied the effects of $E_{2}$ on the involution of the mammary gland in dairy cows and suggested that $E_{2}$ injections led to acceleration of mammary involution. Recently, Delbecchi et al. (2005) showed that $\mathrm{E}_{2}$ injections in non-pregnant cows in mid-lactation increased stanniocalcin (STC) concentrations in both milk and plasma. An increase of STC concentration in milk is a characteristic of mammary gland involution (Hurley, 1989). In lactating cows, a decline in milk production after the peak of lactation is caused by the regression of the 
secretory tissue, a reduction of alveolar size and a loss of MEC (Wilde \& Knight, 1989). During this period, MEC undergo apoptosis to decrease the cell number within the mammary tissue.

The effect of $E_{2}$ on MEC is highly dependent on the model used (Russo et al. 1998). The results can differ between invitro and in-vivo models, animals and humans or cancer MECs and normal MECs. For example, in breast cancer, there is plenty of evidence indicating that oestrogens play a role in the development and progression of the cancer (Jordan et al. 2005). Oestrogen stimulates proliferation and inhibits apoptosis through oestrogen receptor-mediated mechanisms in different cell types. Interestingly, recent studies in vitro have demonstrated that MCF-7 breast cancer cells are able to modify their response to $E_{2}$ treatment by switching from a proliferative state to an apoptotic state (Lewis et al. 2005). Therefore, many trials in vitro and in vivo have indicated that the $E_{2}$ effect is driven by the MEC environment, which controls $E_{2}$ sensitivity and mediates specific signalling pathways.

We thus hypothesized that proliferative or apoptotic effects of $E_{2}$ on MECs could be influenced by the physiological status of the cells. MAC-T cells are a good model to study the effect of sex steroids on MEC because they behave similarly to primary MEC removed from the mammary tissue extracts of heifers (Berry et al. 2003b) and they are sensitive to sex steroids (Zarzynska et al. 2005). Thus, the objectives of this study were to investigate in vitro the effect of $E_{2}$ on MECs by mimicking two physiological statuses (active and early apoptotic MECs) using MAC-T cells. To some extent, active and early apoptotic MECs could be respectively compared with newly generated MECs in early- and mid- lactation mammary gland and senescent MECs in late-lactation mammary gland.

\section{Materials and methods}

\section{Cell culture and treatment}

The MAC-T cell line was established by Huynh et al. (1991). MAC-T cells were grown in high-glucose Dulbecco's Modified Eagle Medium (DMEM; Dominique Dutscher, Brumath, France) supplemented with $10 \%$ fetal calf serum (A15-101, PAA, Les Mureaux, France), $100 \mathrm{U} / \mathrm{ml}$ of penicillin-streptomycin-fungizone (Dominique Dutscher) and $5 \mu \mathrm{g} / \mathrm{ml}$ of bovine insulin (Dominique Dutscher). Cells were maintained at $37^{\circ} \mathrm{C}$ in a humidified atmosphere containing $5 \% \mathrm{CO}_{2}$ and passaged twice a week (cells reached confluency within $2-3 \mathrm{~d}$ ). Cells were plated either in $75-\mathrm{cm}^{2}$ flasks $48 \mathrm{~h}$ before drug treatment $\left(2 \times 10^{6}\right.$ cells/ flask), or in a 96-well microplate (2000 cells/well). In the first part of this study, cells were treated for $48 \mathrm{~h}$ with pharmacological doses of $17 \beta$-oestradiol: $1 \times 10^{-9}$, $1 \times 10^{-8}, 1 \times 10^{-7}$ and $1 \times 10^{-6} \mathrm{~mol} / \mathrm{ml}$ (E4389, Sigma Aldrich Chimie, Lyon, France) (treatments are considered to be at physiological doses from $1 \times 10^{-12}$ to $1 \times 10^{-9} \mathrm{~mol} / \mathrm{ml}$ ). Controls cells did not receive oestradiol. In the second part of this study, cells were treated with $10 \mu \mathrm{M}$ camptothecin (CPT) (C9911, Sigma Aldrich Chimie) to induce apoptosis, and supplemented or not with $1 \times 10^{-7} \mathrm{~mol} / \mathrm{ml} \mathrm{E}_{2}\left(\mathrm{CPT} / \mathrm{E}_{2}\right.$ and CPT respectively) for $2,6,24$ and $48 \mathrm{~h}$ prior to collection. Two additional treated groups were used: a batch of cells treated with $1 \times 10^{-7} \mathrm{~mol} / \mathrm{ml} \mathrm{E}_{2}$ only and a control batch that received neither CPT nor $E_{2}$ (Control).

The 96-well microplates were used for cell viability and proliferation assessment, whereas flasks were used for Caspases 3/7 activity measurement, western blotting and flow cytometry analyses. MAC-T cells in flasks were trypsinized using $0 \cdot 25 \%$ trypsin/EDTA (Sigma Aldrich Chimie). Medium from individual flasks, which could contain dead, floating cells, was collected and mixed with adherent cells from the same flask. The cells were collected, centrifuged at $1000 \mathrm{~g}$ at $4{ }^{\circ} \mathrm{C}$ for $5 \mathrm{~min}$ and washed with cold PBS.

\section{Cell viability and proliferation}

For the cell viability [3-(4,5-dimethylthiazol-2-yl)-2,5diphenyltetrazolium bromide MTT (Sigma Aldrich Chimie) test] and proliferation [Cyquant test (Thermo Fisher Scientific, Illkirch, France)] assays, cells were plated at a density of 2000 cells per well. The cells were then treated with or without oestradiol $\left(1 \times 10^{-7} \mathrm{~mol} / \mathrm{ml}\right)$ and camptothe$\operatorname{cin}(10 \mu \mathrm{m})$ for $48 \mathrm{~h}$.

Cell viability was assessed in 96-well microplates using the 3-(4,5-dimethylthiazol-2-yl)-2,5-diphenyltetrazolium bromide MTT test (Sigma Aldrich Chimie). The medium was removed at the end of the treatment period. After washing with PBS, cell monolayers were exposed to $200 \mu \mathrm{l}$ of MTT solution $\left(0.5 \mathrm{mg} / \mathrm{ml}\right.$ in PBS) at $37{ }^{\circ} \mathrm{C}$ in a humidified $5 \% \mathrm{CO}_{2}$ incubator for $2 \mathrm{~h}$ to allow blue formazan crystals to be produced via the mitochondrial enzyme succinate dehydrogenase. The MTT solution was discarded; the cells were washed with PBS; and the formazan crystals were solubilized with $200 \mu \mathrm{l}$ of DMSO per well (Sigma Aldrich Chimie) using gentle agitation for $10 \mathrm{~min}$ at room temperature. Then, the 96-well plates were measured spectrophotometrically at $540 \mathrm{~nm}$ using a Multiskan Spectrum microplate reader (Thermo Fisher Scientific) equipped with a spectrophotometer. Cell viability analysis was repeated 3 times.

Cell proliferation rates in 96-well microplates were estimated using the Cyquant Cell Proliferation assay (Thermo Fisher Scientific) according to the manufacturer's instructions. The amount of DNA in the wells was measured after removal of the medium and washing with PBS. The DNA was then frozen at $-80^{\circ} \mathrm{C}$ until the day of the analysis. Cyquant fluorescent dye diluted 400 -fold in $1 \times$ lysis buffer was added to the wells. After $5 \mathrm{~min}$ of incubation, the fluorescence intensity of each sample was measured at 485/ $530 \mathrm{~nm}$ using a Mithras LB940 fluorescence microplate reader (Berthold Technologies, Thoiry, France). A standard curve using a dilution series of cells ranging from 
A

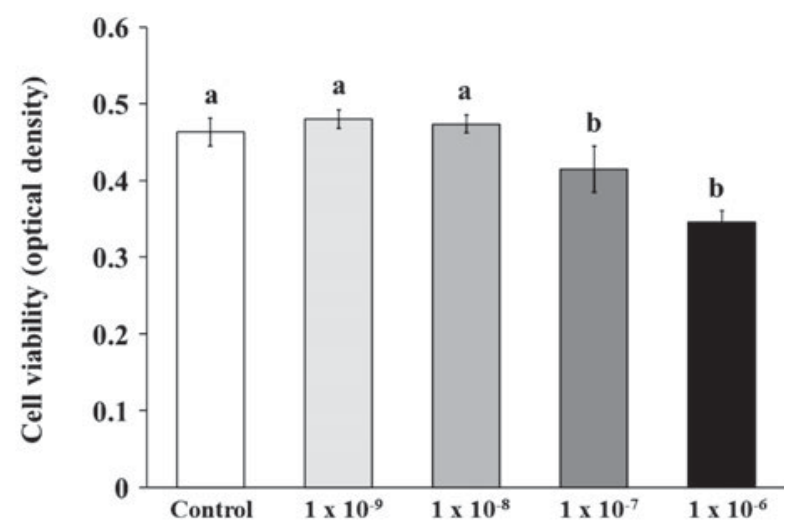

B

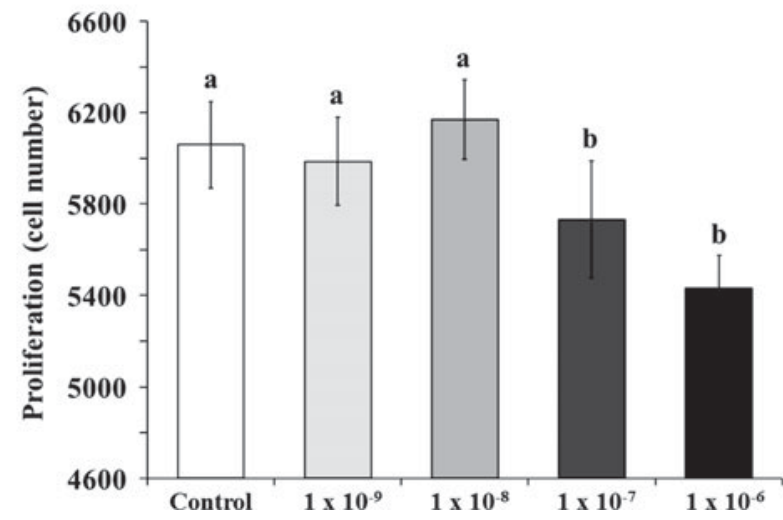

Fig. 1. Effects of $E_{2}$ on $M A C-T$ cell viability and proliferation. MAC-T cells were cultured for $48 \mathrm{~h}$ in medium without $\mathrm{E}_{2}$ (Control) or containing different concentrations of $E_{2}\left(1 \times 10^{-9} \mathrm{~mol} / \mathrm{ml}\right.$ to $1 \times 10^{-6} \mathrm{~mol} / \mathrm{ml}$ ). (a) Cell viability was assayed using the MTT method. (b) Cell numbers were determined using the Cyquant method. Bars represent means $\pm S D$. ${ }^{a}$ b within a variable, values with different superscript letters are significantly different $(P<0 \cdot 05)$. Experiments were repeated at least three times

300 to 40000 cells was generated to convert sample fluorescence values into cell numbers. Cell proliferation analysis was repeated 3 times.

\section{Caspases 3/7 activity}

Caspases 3/7 activity was evaluated with a luminogenic assay using the caspases 3/7 Glo kit (Promega France) according to the manufacturer's recommendations. Briefly, cell lysates $(10 \mu \mathrm{g})$ were incubated with $200 \mu \mathrm{l}$ of the caspases 3/7 Glo buffer for $1 \mathrm{~h}$ at room temperature. Then, the luminescence generated by substrate cleavage was measured using a Mithras luminometer (Perkin Elmer, Courtaboeuf, France) at $380 \mathrm{~nm}$ (excitation wavelength) and $455 \mathrm{~nm}$ (emission wavelength). The measurement of caspases $3 / 7$ activity was repeated 3 times.

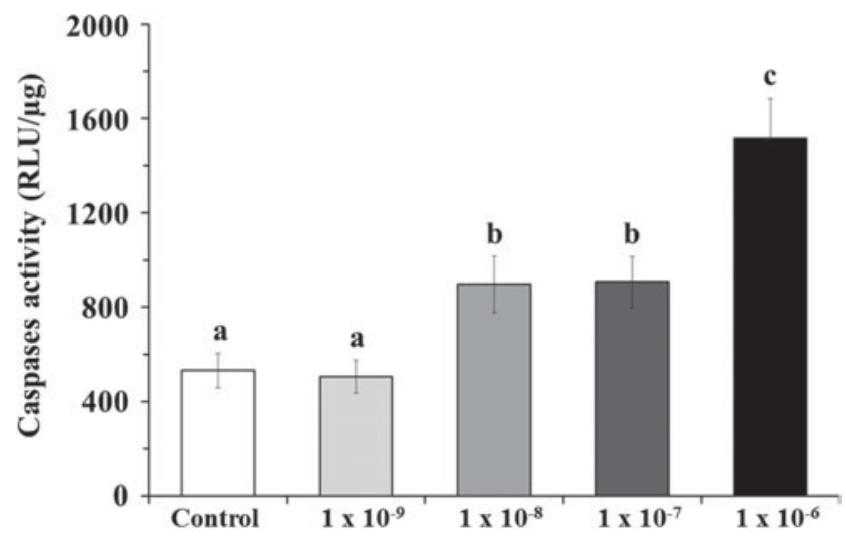

Fig. 2. Effects of $E_{2}$ on caspases activity. MAC-T cells were cultured for $48 \mathrm{~h}$ in medium containing $0 \mathrm{~mol} / \mathrm{ml} \mathrm{E}_{2}$ (Control) or different concentrations of $E_{2}\left(1 \times 10^{-9} \mathrm{~mol} / \mathrm{ml}\right.$ to $\left.1 \times 10^{-6} \mathrm{~mol} / \mathrm{ml}\right)$. Cells were lysed in MPER buffer for total protein extraction. Caspases 3/7 activity was assessed in total protein extracts using a Caspase Glo kit. ${ }^{a, b, c}$ within a variable, values with different superscript letters are significantly different $(P<0 \cdot 05)$. The experiment was independently repeated three times

\section{Protein extraction and Western blot analysis}

Total proteins were extracted from pelleted cells using the Mammalian Protein Extraction Reagent (MPER, Thermo Fisher Scientific) containing a proteinase inhibitor mixture (Thermo Fisher Scientific). The soluble protein fraction was collected after centrifugation at $13000 \mathrm{~g}$ at $4{ }^{\circ} \mathrm{C}$ for $10 \mathrm{~min}$, and protein concentrations were determined using the BCA Protein Assay kit according to the manufacturer's instructions (Thermo Fisher Scientific). Lysates were combined with sample buffer $(50 \mathrm{~mm}-\mathrm{TrisHCl}(\mathrm{pH} 6 \cdot 8), 2 \%$ SDS, $0 \cdot 1 \%$ bromophenol blue, $20 \%$ glycerol and $0 \cdot 1$ m-dithiothreitol), boiled for $5 \mathrm{~min}$ at $95^{\circ} \mathrm{C}$, and resolved using SDS-PAGE.

Equal amounts of protein $(10 \mu \mathrm{g})$ were separated on $4-12 \%$ NuPage gradient gels (Thermo Fisher Scientific) via SDS-PAGE and transferred electrophoretically to polyvinylidene difluoride membranes (Amersham, Courtaboeuf, France) at $100 \mathrm{~V}$ for $60 \mathrm{~min}$. The membranes were incubated with blocking solution (5\% dry skimmed milk dissolved in Tris-buffered saline Tween (TBS-T) buffer, $50 \mathrm{~mm}$-Tris-HCl (pH 8.6), $150 \mathrm{~mm}-\mathrm{NaCl}$ and $0 \cdot 1 \%$ Tween) for $30 \mathrm{~min}$. A set of prestained molecular mass standards (Thermo Fisher Scientific) was run in each gel. Detection of PARP cleavage, progesterone receptor (PR) and oestradiol receptor alpha $(E R \alpha)$ was accomplished by incubating the membranes overnight $\left(4^{\circ} \mathrm{C}\right)$ with a rabbit polyclonal anti-PARP antibody (9542, Ozyme, St Quentin Yvelines, France), a mouse monoclonal anti-PR antibody (PN IM1546, clone PR10A9, Immunotech SAS, Marseille, France) and a rabbit polyclonal anti-ER $\alpha$ antibody (sc-543, clone HC-20, Santa Cruz Biotechnology, Heidelberg, Germany), respectively. Actin levels, recognized using a mouse monoclonal anti- $\beta$-actin antibody (A5441, Sigma Aldrich Chimie), were used as an internal control. The three primary antibodies were used 
A
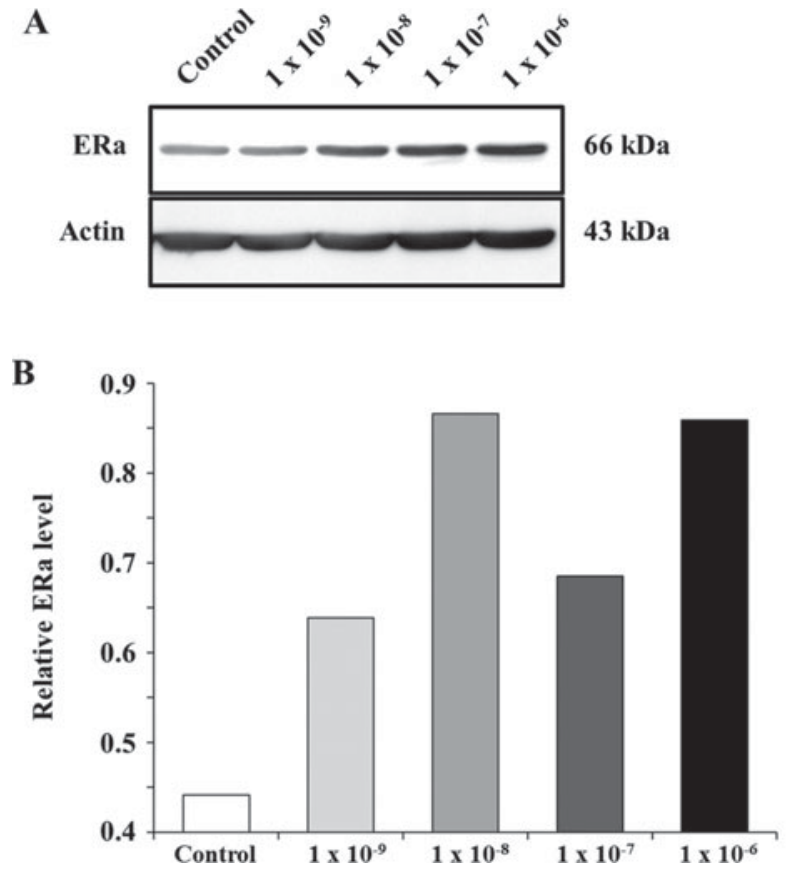
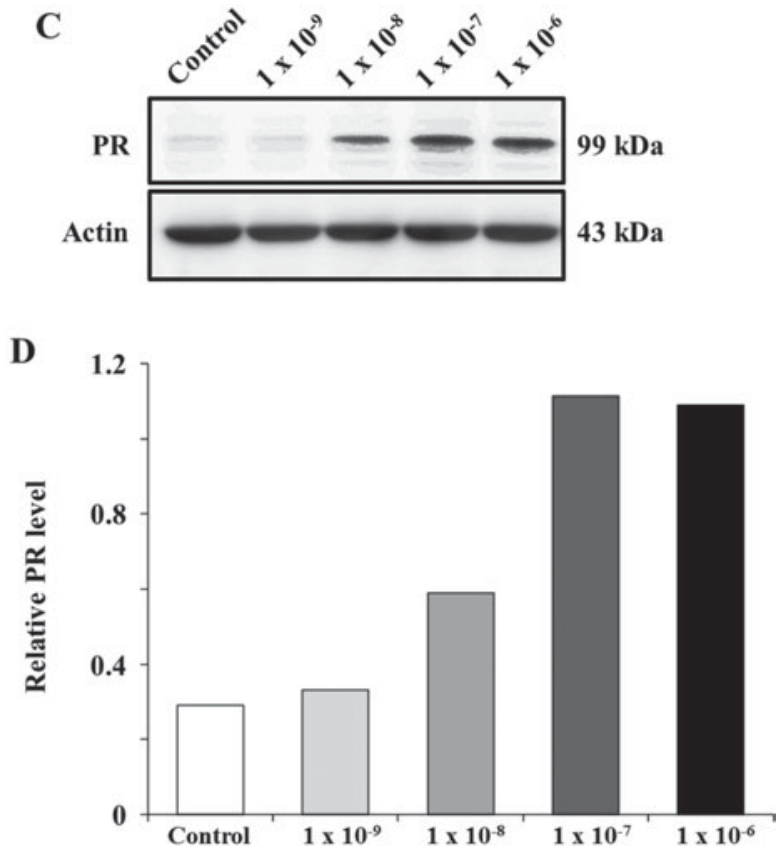

Fig. 3. Effects of $E_{2}$ on oestrogen receptivity and progesterone receptor levels. MAC-T cells were cultured for $48 \mathrm{~h}$ in medium without $\mathrm{E}_{2}$ (Control) or containing different concentrations of $\mathrm{E}_{2}\left(1 \times 10^{-9} \mathrm{~mol} / \mathrm{ml}\right.$ to $\left.1 \times 10^{-6} \mathrm{~mol} / \mathrm{ml}\right)$. (a) The cells were lysed in MPER buffer for total protein extraction, and $15 \mu \mathrm{g}$ of protein was analysed using electrophoresis and Western blotting (ER $\alpha$ and Actin). (b) Each band was quantified using a molecular imager, and for each treatment, $\mathrm{ER \alpha}(66 \mathrm{kDa})$ data were normalized using actin $(43 \mathrm{kDa})$ data. (c) The cells were lysed in MPER buffer for total protein extraction, and $15 \mu \mathrm{g}$ of protein was analysed using electrophoresis and Western blotting (PR and Actin). (d) Each band was quantified using a molecular imager, and for each treatment, PR (99 kDa) data were normalized using actin $(43 \mathrm{kDa})$ data

at $1: 1000$. The membranes were incubated for $1 \mathrm{~h}$ with the appropriate secondary antibody coupled to horseradish peroxidase (HRP; Dako France SAS, Trappes, France) used at 1:2500, which was visualized using an ECL kit (Thermo Fisher Scientific) and the ImageQuant LAS4000 Biomolecular Imager digital imaging system (GE Healthcare, Velizy-Villacoublay, France). Images generated as gel files were analysed using the corresponding ImageQuant TL software (GE Healthcare). For each protein, protein extraction and Western blot analysis were repeated 2 times.

\section{Flow cytometry analysis of Pl/Annexin-V labelling}

Annexin-V and PI double labelling was used to visualize apoptotic and necrotic cells using the Alexa Fluor 488 Annexin-V/Dead cell apoptosis kit (Thermo Fisher Scientific) procedure according to the manufacturer's recommendations.

Cells were resuspended in $100 \mu \mathrm{l}$ of binding buffer. Then, cells were incubated for $15 \mathrm{~min}$ at room temperature in darkness with Annexin-V-FITC ( $5 \mu \mathrm{g} / \mathrm{ml})$ and PI $(1 \mu \mathrm{g} / \mathrm{ml})$. After the incubation period, cells were diluted 5 -fold in $400 \mu \mathrm{l}$ of annexin-binding buffer, mixed gently and immediately analysed by flow cytometry. The following controls were used to set up quadrants: unstained cells, cells labelled with Annexin-V-FITC alone (without PI), and cells labelled with PI alone (without Annexin-V-FITC).
For each sample, $2 \times 10^{4}$ events were analysed. Flow cytometry analyses were performed using a MACSQuant Analyzer (Miltenyi Biotec SAS, Paris, France), followed by analysis using MACSQuantify software (Miltenyi Biotec SAS). Flow cytometry analysis was repeated 3 times.

\section{Observation of cells}

Cells were observed at $10 \times$ magnification, objective length 160/0.17, using phase contrast microscopy (Olympus CK2; Olympus France, Rungis, France), and images were generated.

\section{Statistical analysis}

Data on cell viability, flow cytometry, caspases activity and proliferation are expressed as means \pm SD. Data were subjected to a Student's $t$ test to compare the mean values. Statistical analyses were performed using the $\mathrm{R}$ software package. Effects were considered statistically significant at $P<0 \cdot 05$.

\section{Results}

\section{Effect of $E_{2}$ on MAC-T cell proliferation and apoptosis}

We first studied the effect of $E_{2}$ on the viability of the bovine MAC-T cell line. As shown in Fig. 1(a), $E_{2}$ treatments 
at increasing doses $\left(1 \times 10^{-9}\right.$ to $\left.1 \times 10^{-6} \mathrm{~mol} / \mathrm{ml}\right)$ applied over $48 \mathrm{~h}$ induced a decrease in MAC-T cell viability $(-11 \%$ at $1 \times 10^{-7} \mathrm{~mol} / \mathrm{ml}$ and $-26 \%$ at $\left.1 \times 10^{-6} \mathrm{~mol} / \mathrm{ml}, P<0 \cdot 01\right)$. Similar results were obtained after 24 and $72 \mathrm{~h}$ of $\mathrm{E}_{2}$ treatment (data not shown).

The same $E_{2}$ doses were used to test the effect of $E_{2}$ on the proliferation of MAC-T cells (Fig. 1b). As observed based on cell viability, $E_{2}$ treatments at increasing doses $\left(1 \times 10^{-9}\right.$ to $1 \times 10^{-6} \mathrm{~mol} / \mathrm{ml}$ ) applied over $48 \mathrm{~h}$ induced a decrease in MAC-T cell numbers $\left(-6 \%\right.$ at $1 \times 10^{-7} \mathrm{~mol} / \mathrm{ml}$ and $-11 \%$ at $\left.1 \times 10^{-6} \mathrm{~mol} / \mathrm{ml}, P<0 \cdot 01\right) . E_{2}$ treatments had no significant effect on MAC-T cell numbers and viability at doses of $1 \times 10^{-9}$ and $1 \times 10^{-8} \mathrm{~mol} / \mathrm{ml}$.

Caspases $3 / 7$ activities were quantified to determine the apoptotic potential of $E_{2}$ on bovine MECs in vitro. We detected active forms of caspases $3 / 7$ beginning at an $E_{2}$ dose of $1 \times 10^{-8} \mathrm{~mol} / \mathrm{ml}$ after $48 \mathrm{~h}$ of treatment. As shown in Fig. 2, the $E_{2}$ treatments led to an increase in caspases $3 / 7$ activity in a dose-dependent manner in MAC-T cells, suggesting that $E_{2}$ induced apoptosis in the MAC-T cells (by $2 \cdot 3$ and $3 \cdot 3$-fold at $1 \times 10^{-7}$ and $1 \times 10^{-6} \mathrm{~mol} / \mathrm{ml} \mathrm{E}_{2}$, respectively).

\section{Effect of $E_{2}$ on the expression of an oestrogen-dependent protein}

The $E_{2}$ receptivity of MAC-T cells was assessed by Western blot quantification of the oestrogen nuclear receptor, $E R \alpha$ (Fig. 3a). Cells from the five groups expressed ER $\alpha$, and its expression was increased in $E_{2}$ treated cells whatever the treatment dose (Fig. 3b).

The progesterone receptivity of MAC-T cells was assessed by Western blot quantification of PR (Fig. 3c). The PR expression was increased in $\mathrm{E}_{2} 1 \times 10^{-8}, 1 \times 10^{-7}$ and $1 \times 10^{-6} \mathrm{~mol} / \mathrm{ml}$ treatment groups and was strongly stimulated by $1 \times 10^{-7}$ and $1 \times 10^{-6} \mathrm{~mol} / \mathrm{ml} \mathrm{E}_{2}$ doses at $48 \mathrm{~h}$.

Quantification of PR levels (Fig. 3d) revealed that the $1 \times 10^{-7} \mathrm{~mol} / \mathrm{ml} \mathrm{E}_{2}$ dose induced the maximum level in the MAC-T cells (3-fold compared with the control). These results suggested that MAC-T cells are sensitive and receptive to oestradiol treatment and that oestradiol is able to activate an $E_{2}$ target protein.

\section{Effect of $E_{2}$ on apoptosis induction in MAC-T cells}

Camptothecin is a cytotoxic quinoline alkaloid, often used in breast cancer treatments, that inhibits the DNA enzyme topoisomerase I. We used this drug to induce an apoptotic state in MAC-T cells and to examine the effects of $E_{2}$ on cells engaged in cell death to mimic MEC status during late lactation. We checked beforehand that we induced apoptosis of MAC-T cells with $10 \mu \mathrm{M}$ of CPT (data not shown).

First, we observed cell morphology on MAC-T cells treated with CPT, $\mathrm{E}_{2}\left(1 \times 10^{-7} \mathrm{~mol} / \mathrm{ml}\right)$ or $\mathrm{E}_{2}\left(1 \times 10^{-7} \mathrm{~mol} /\right.$ $\mathrm{ml}$ ) in combination with CPT $\left(\mathrm{CPT} / \mathrm{E}_{2}\right)$. MAC-T cells treated with CPT underwent significant changes with respect to their
A
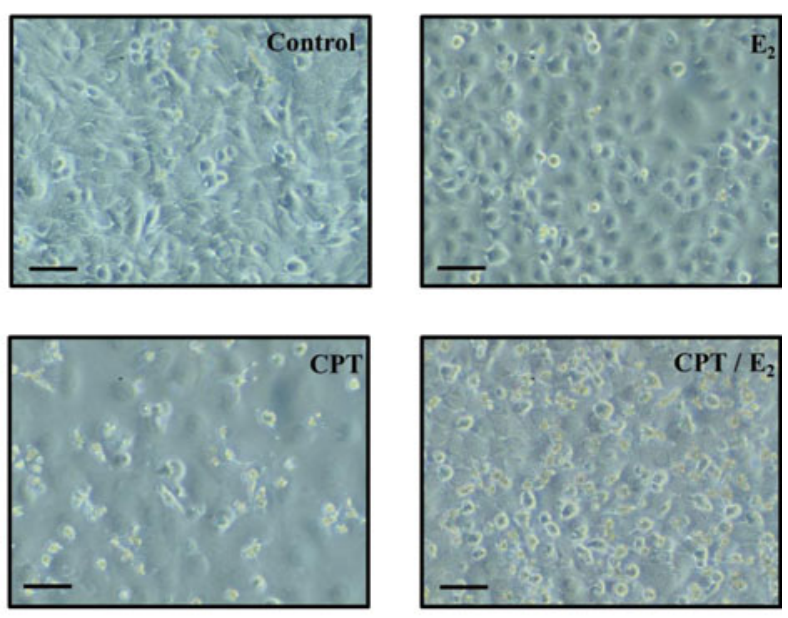

B

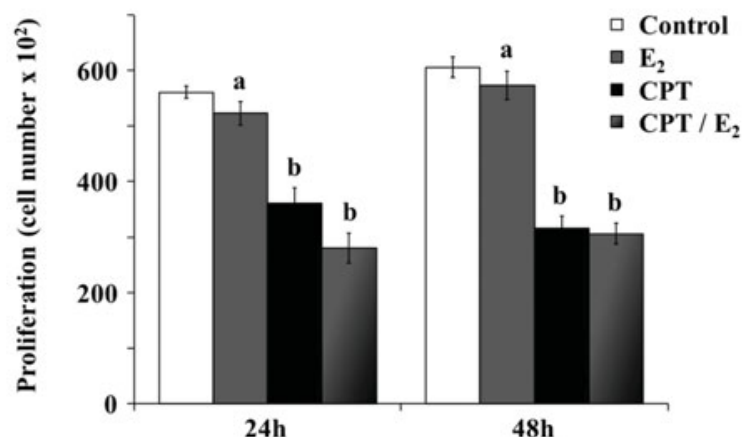

Fig. 4. Effects of $E_{2}$ on apoptosis-induced MAC-T cell morphology and proliferation. MAC-T cells were cultured for $48 \mathrm{~h}$ in medium without $\mathrm{E}_{2}$ (Control) or containing $1 \times 10^{-7} \mathrm{~mol} / \mathrm{ml}$ of $\mathrm{E}_{2}\left(\mathrm{E}_{2}\right), 10 \mu \mathrm{M}$ of CPT (CPT) or $1 \times 10^{-7} \mathrm{~mol} / \mathrm{ml}$ plus $10 \mu \mathrm{M}$ CPT $\left(C P T / \mathrm{E}_{2}\right)$. (a) Treated and untreated cells were observed using microscopy. Scale bars represent $10 \mu \mathrm{m}$. (b) Cell numbers were determined using the Cyquant method. ${ }^{a, b}$ within a variable, values with different superscript letters are significantly different $(P<0 \cdot 05)$. Experiments were repeated at least three times

cell shape and surface (Fig. 4a), which was less observable following treatment with $\mathrm{E}_{2}$ alone. Interestingly, cells treated with a combination of $E_{2}$ and CPT appeared to be rounded with numerous plasma membrane deformations and lost adhesion to the substrate. Moreover, proliferation assays (Fig. 4b) confirmed that $E_{2}$ had a negative effect by decreasing cell numbers after 24 and $48 \mathrm{~h}$ of treatment. Cell proliferation was further decreased by the addition of CPT; however, addition of $\mathrm{E}_{2}$ to $\mathrm{CPT}$ did not cause an additional decline.

Next, we extensively analysed MAC-T cell apoptosis in response to $E_{2} \pm$ CPT. Flow cytometry results indicated that long-term (48 h) $\mathrm{CPT} / \mathrm{E}_{2}$ treatment led to an increase in Annexin- $\mathrm{V}$ and $\mathrm{PI}$ positive cell number $(+3$ and $7 \%$, respectively). Interestingly, as shown in Fig. 5 and Table 1 , $E_{2}$ was able to induce a switch from an early apoptotic stage (Annexin-V positive cells) to a late apoptotic stage (PI/ Annexin- $V$ double-labelled cells). 


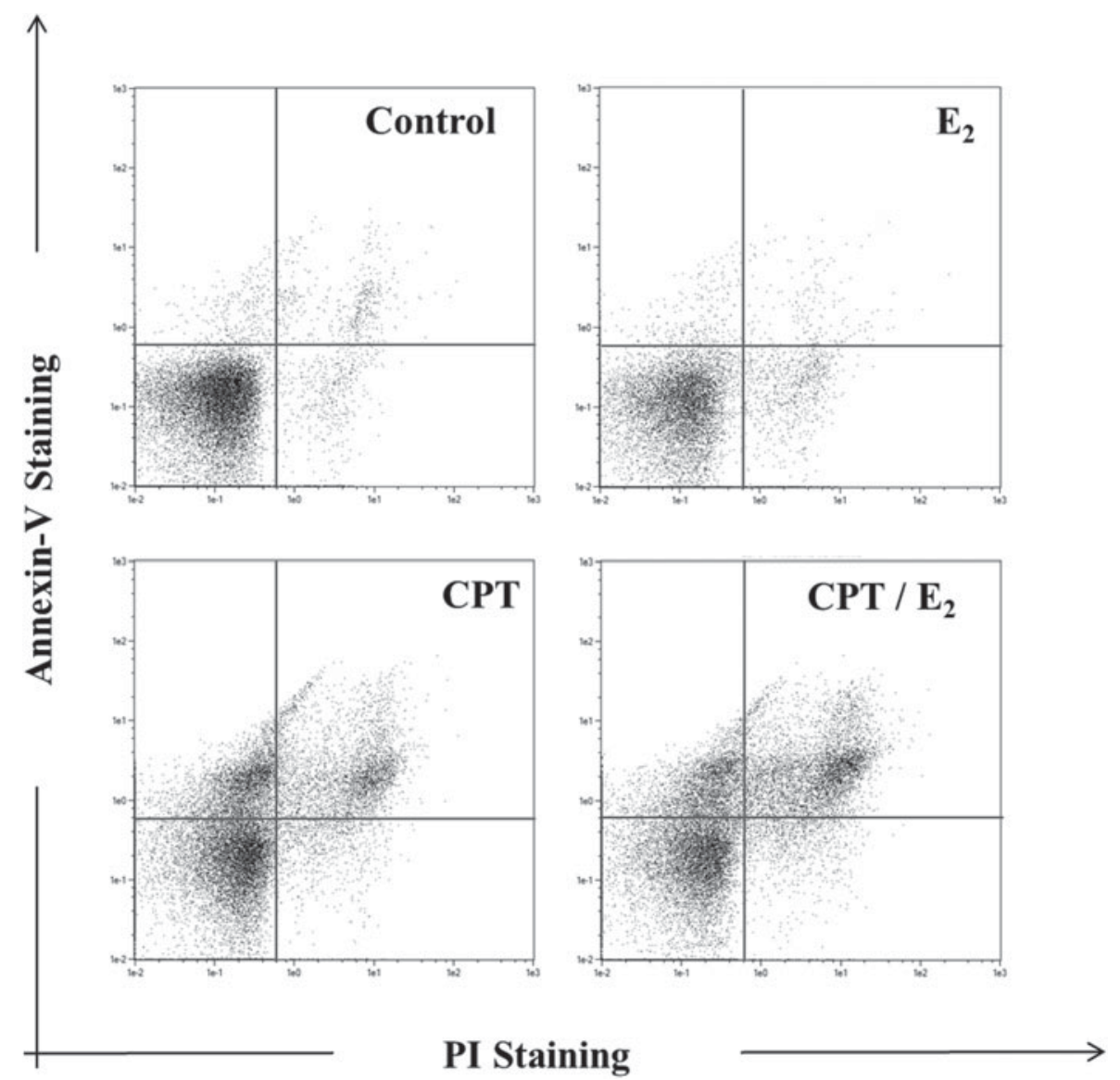

Fig. 5. Effects of $E_{2}$ on apoptosis-induced MAC-T cell apoptosis. MAC-T cells were cultured for $48 \mathrm{~h}$ in medium without $E_{2}($ Control) or containing $1 \times 10^{-7} \mathrm{~mol} / \mathrm{ml}$ of $\mathrm{E}_{2}\left(\mathrm{E}_{2}\right), 1 \mu \mathrm{M}$ of CPT (CPT) or $1 \times 10^{-7} \mathrm{~mol} / \mathrm{ml}$ plus $10 \mu \mathrm{M}$ CPT $\left(\mathrm{CPT} / \mathrm{E}_{2}\right)$. Annexin- $\mathrm{V}$ and PI staining were analysed using flow cytometry. Each plot corresponds to 20000 events

\section{Caspases signalling pathways induced by $E_{2}$ treatment}

We next studied the effects of $E_{2}, C P T$ and $C P T / E_{2}$ on several MAC-T cell apoptosis markers. We treated cells at various time points $(2,6,24$ and $48 \mathrm{~h})$ with drug combinations as described above and measured caspases 3/7 activity. We found that $E_{2}$ had an additive effect on the action of CPT by inducing an increase in caspases $3 / 7$ activity after $24 \mathrm{~h}$ of treatment (Fig. 6a). Indeed, from $24 \mathrm{~h}, \mathrm{E}_{2}$ enhanced apoptosis in MAC-T cells in which apoptosis had been induced by CPT. PARP is a protein involved in DNA repair that can be cleaved and inactivated by caspases. Here we observed that the $\mathrm{CPT} / \mathrm{E}_{2}$ treatment induced cleavage of PARP after 24 and $48 \mathrm{~h}$ of treatment (Fig. 6b). Quantification of cleaved PARP levels revealed that the additional treatment with $\mathrm{E}_{2}$ increased these levels to 6 and $25 \%$ after 24 and $48 \mathrm{~h}$ of treatment, respectively, compared with CPT alone.

\section{Discussion}

In this study we investigated the effect of $E_{2}$ on MAC-T cells in vitro, considering two physiological states: active MECs and early apoptotic MECs. MAC-T cells are mammary alveolar bovine cells able to secrete milk proteins and are receptive to sex steroids.

First we studied the effect of different concentrations of $E_{2}$ on MAC-T cells (active MECs). In the present study, MAC-T cells expressed ER $\alpha$ and the use of pharmacological doses of $E_{2}$ (from $10^{-6} \mathrm{M}$ to $10^{-3} \mathrm{M}$ ) enhanced the transcription of PR. The pr gene expression, and by this way its protein transcription, is known to be positively regulated by $E_{2}$. Our results highlighted that MAC-T cells express PR and that the level of PR expression is $E_{2}$ dose dependent, thereby confirming that MAC-T cells are responsive to $E_{2}$. The maximal PR protein level observed was induced by a dose of $10^{-4} \mathrm{ME}_{2}$. Similarly, treating MAC-T cells with increasing doses of $E_{2}$ led to a reduction in their viability and proliferation. We attempted to connect this anti-proliferative effect to an apoptotic mechanism, and we showed that $E_{2}$ was able to activate key proteins involved in programmed cell death: the caspases. This is the first study to describe a direct apoptotic effect of $E_{2}$ on bovine MEC. Woodward et al. (1993) demonstrated that the growth of MAC-T cells was not stimulated by $E_{2}$ at any dose. Indeed, here we 
Table 1. Percentages of Annexin- $\mathrm{V}, \mathrm{PI}$ and Pl/Annexin- $\mathrm{V}$ positive cells determined by flow cytometry after 24 and $48 \mathrm{~h}$ of treatment. Results are expressed as percentages of total cell number. MAC-T cells were cultured for 24 or $48 \mathrm{~h}$ in medium without $\mathrm{E}_{2}$ (Control) or containing $1 \times 10^{-7} \mathrm{~mol} / \mathrm{ml}$ of $\mathrm{E}_{2}\left(\mathrm{E}_{2}\right), 10 \mu \mathrm{M}$ of CPT $(\mathrm{CPT})$ or $1 \times 10^{-7} \mathrm{~mol} / \mathrm{ml} \mathrm{E}_{2}$ plus $10 \mu \mathrm{M} \mathrm{CPT}\left(\mathrm{CPT} / \mathrm{E}_{2}\right)+$

\begin{tabular}{|c|c|c|c|c|}
\hline \multirow[b]{2}{*}{$24 \mathrm{~h}$} & Control & $E_{2}$ & CPT & $\mathrm{CPT} / \mathrm{E}_{2}$ \\
\hline & $2 \cdot 64 \pm 0 \cdot 53^{\mathrm{a}}$ & $2 \cdot 64 \pm 0 \cdot 16^{\mathrm{a}}$ & $12 \cdot 71 \pm 0 \cdot 06^{\mathrm{b}}$ & $15 \cdot 03 \pm 0 \cdot 38^{c}$ \\
\hline PI positive cells, $\%$ & $2 \cdot 00 \pm 0 \cdot 30^{a^{\prime}}$ & $3 \cdot 21 \pm 0 \cdot 24^{b^{\prime}}$ & $5 \cdot 05 \pm 0 \cdot 09^{c^{\prime}}$ & $3 \cdot 64 \pm 0 \cdot 24^{b^{\prime}}$ \\
\hline $\mathrm{Pl} / \mathrm{An}-\mathrm{V}$ positive cells, $\%$ & $1 \cdot 71 \pm 0 \cdot 27^{\mathrm{a}^{\prime \prime}}$ & $1 \cdot 25 \pm 0 \cdot 01^{a^{\prime \prime}}$ & $2 \cdot 61 \pm 0 \cdot 09^{b^{\prime \prime}}$ & $4 \cdot 74 \pm 0 \cdot 28^{c^{\prime \prime}}$ \\
\hline An-V positive cells, $\%$ & $3 \cdot 79 \pm 0 \cdot 14^{\mathrm{a}}$ & $7 \cdot 30 \pm 1 \cdot 60^{a}$ & $43 \cdot 34 \pm 1 \cdot 99^{b}$ & $47 \cdot 40 \pm 1 \cdot 13^{c}$ \\
\hline PI positive cells, $\%$ & $2 \cdot 07 \pm 0 \cdot 23^{a^{\prime}}$ & $4 \cdot 71 \pm 0 \cdot 10^{\mathrm{b}^{\prime \prime}}$ & $3 \cdot 79 \pm 0 \cdot 22^{c^{\prime}}$ & $7 \cdot 91 \pm 0 \cdot 57^{\mathrm{d}^{\prime}}$ \\
\hline $\mathrm{Pl} / \mathrm{An}-\mathrm{V}$ positive cells, $\%$ & $1 \cdot 41 \pm 0 \cdot 07^{a^{\prime \prime}}$ & $0.67 \pm 0.09^{a^{\prime \prime}}$ & $13 \cdot 46 \pm 1 \cdot 33^{b^{\prime \prime}}$ & $21 \cdot 37 \pm 1 \cdot 55^{c^{\prime \prime}}$ \\
\hline
\end{tabular}

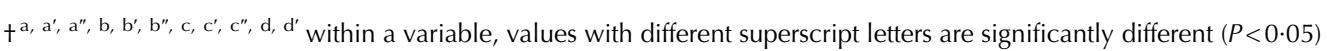
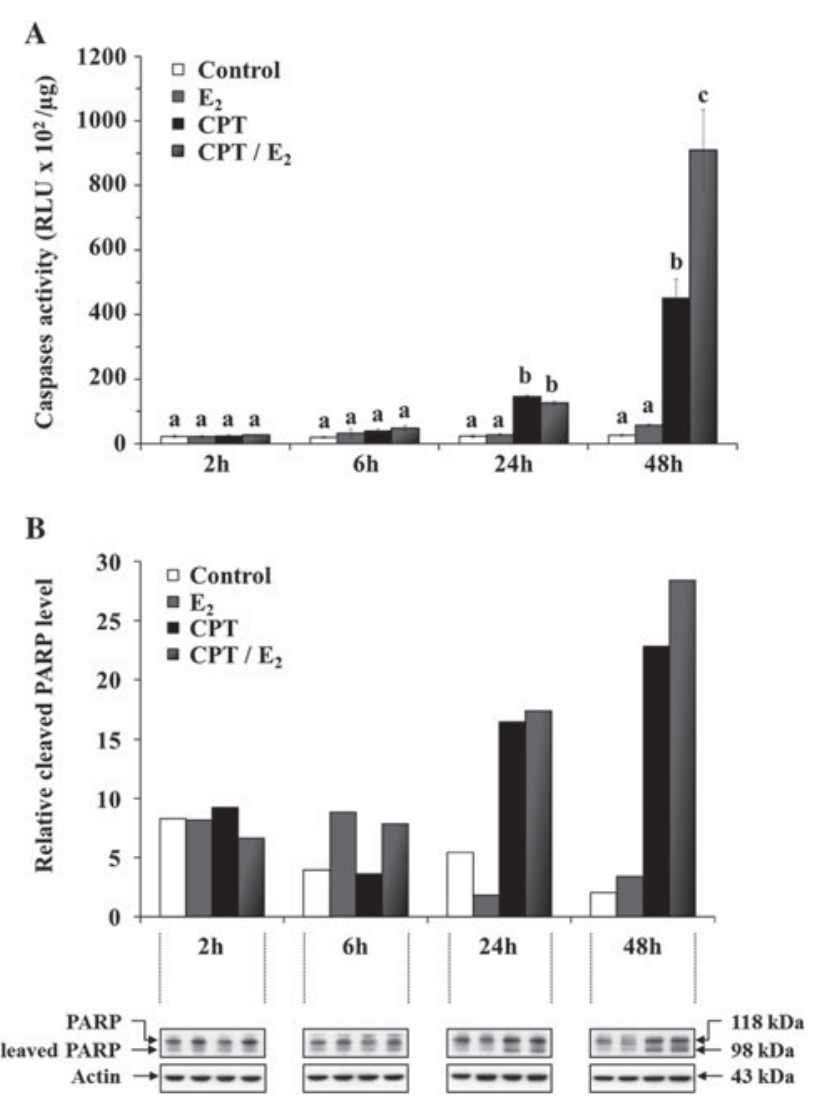

Fig. 6. Effects of $E_{2}$ on apoptosis-induced MAC-T cell apoptosis signalling pathways. MAC-T cells were cultured for $48 \mathrm{~h}$ in medium without $\mathrm{E}_{2}$ (Control) or containing $1 \times 10^{-7} \mathrm{~mol} / \mathrm{ml}$ of $\mathrm{E}_{2}$ $\left(\mathrm{E}_{2}\right), 10 \mu \mathrm{M}$ of CPT $(\mathrm{CPT})$ or $1 \times 10^{-7} \mathrm{~mol} / \mathrm{ml} \mathrm{E}_{2}$ plus $10 \mu \mathrm{M}$ CPT $\left(\mathrm{CPT} / \mathrm{E}_{2}\right)$. (a) Cells were lysed in MPER buffer for total protein extraction. Caspase activation was assessed in total protein extracts using a Caspase Glo kit. The experiment was independently repeated three times. (b) Cells were lysed in MPER buffer for total protein extraction, and $15 \mu \mathrm{g}$ of protein was analysed using electrophoresis and Western blotting. Each band was quantified using a molecular imager, and for each treatment, cleaved PARP data were normalized using actin data. ${ }^{a}$ b, c within a variable, values with different superscript letters are significantly different $(P<0 \cdot 05)$ found that none of our treatment doses of $E_{2}$ were able to induce proliferation in MAC-T cells. On the contrary, the highest doses of $\mathrm{E}_{2}\left(10^{-7} \mathrm{~mol} / \mathrm{ml}\right.$ and $\left.10^{-6} \mathrm{~mol} / \mathrm{ml}\right)$ tested accelerated apoptosis. The effect of $E_{2}$ on cell death marker was described in MAC-T cells by Zarzynska et al. (2005). In this study, the authors observed an increase in transforming growth factor-beta 1 (TGF- $\beta 1$ ) expression in response to $E_{2}$. The apoptosis induced during mammary gland involution involves many intracellular events, including TGF- $\beta 1$ production. Execution of TGF- $\beta 1$-induced apoptosis in bovine MEC occurs through the action of caspases (Kolek et al. 2003).

Thus, in a second part of the experiment, we studied the effect of $E_{2}$ on early apoptotic MAC-T cells. For this purpose, we used camptothecin to induce cell death. Camptothecin was applied either alone or combined with $\mathrm{E}_{2}\left(10^{-7} \mathrm{~mol} / \mathrm{ml}\right)$. Observations of cell morphology and proliferation of MAC-T cells treated for 24 and $48 \mathrm{~h}$ with $\mathrm{E}_{2}$ alone, CPT alone or their combination showed an amplifying effect of $E_{2}$ on the decrease in cell numbers and morphological modifications (disorganization of the plasma membrane and presence of apoptotic bodies). Flow cytometry analysis enabled us to link this rise in cell loss to an increase in apoptosis. Indeed, after $48 \mathrm{~h}$ of treatment, $\mathrm{E}_{2}$ alone had a weak apoptotic effect on MAC-T cells compared with the apoptosis rate induced by CPT, whereas $E_{2}$ strongly increased apoptosis in early apoptotic MAC-T cells $(+7 \%$ of $\mathrm{Pl} /$ Annexin-V positive cells). Many studies have indicated that $E_{2}$ acts as a mitogenic factor by stimulating proliferation and inhibiting cell death in different cell types. Here, $E_{2}$ had an opposite effect and was able to induce apoptosis. However, various models exist and indicate that $E_{2}$ is able to induce apoptosis in different cell types, in particular in human MECs. A putative oestrogen receptor response element has been identified in the Fas $L$ gene (extrinsic apoptotic pathway), which activates the Fas/FasL pathway (Mor et al. 2000), responsible for caspases activation. In a human breast cancer cell line, $E_{2}$ treatment severely increased the expression of several proapoptotic proteins and led to a loss of the mitochondrial potential and to the activation of caspases 7 and 9. Caspase 
activation induces cleavage of the protein PARP, which is an enzyme involved in DNA repair in response to environmental stress. Thus, PARP cleavage reflects an apoptotic state and activated caspases. We showed that $E_{2}$ was able to accelerate apoptosis in early apoptotic MAC-T cells by activating caspases, leading to an increase in PARP cleavage. Taken together, these results suggest that $E_{2}$ may have different responsiveness dependent on the cell physiological status.

Recently, we published a study indicating that suppression of ovarian steroids by ovariectomy in non-pregnant lactating cows limited the decline in milk yield after the peak of lactation, in the second half of lactation (Yart et al. 2012b). After 14 months of lactation, this resulted in a $36 \%$ higher milk yield for ovariectomized cows compared with control non-pregnant cows. Interestingly, the molecular analyses performed on mammary tissue samples collected on these cows after 14 months of lactation revealed that the limited decline in milk yield measured in ovariectomized cows was related to a decrease in MEC apoptosis, evidenced by a decrease in PARP protein abundance. Here, we have demonstrated that $E_{2}$ is able to activate caspases in early apoptotic cells and that this activation later involves PARP cleavage. Moreover, the difference in cleaved PARP protein abundance after $48 \mathrm{~h}$ of treatment was more important between CPT and CPT/E $E_{2}$ groups than between Control and $\mathrm{E}_{2}$ groups. This suggests that the apoptotic processes that are increased in the presence of ovarian steroids in the late-lactating mammary gland, are similar to those observed in vitro in early apoptotic MECs, treated with $\mathrm{E}_{2}$ during $48 \mathrm{~h}$.

It is now well established that the decline in milk yield that follows the peak of lactation is the consequence of a gradual increase in apoptotic MEC number (Capuco et al. 2001; Stefanon et al. 2002). Oestradiol has been identify as a potential factor involved in the decline in milk yield insofar as its administration in mid- or late-lactating cows induces a strong decrease in milk yield (Mollett et al. 1976) and accelerates mammary gland involution (Athie et al. 1996; Delbecchi et al. 2005). Delbecchi et al. (2005) showed that $E_{2}$ injections in non-pregnant cows in mid-late lactation induced an $81 \%$ decrease in the milk yield after $11 \mathrm{~d}$ of treatment, related to a decrease in $\beta$-casein gene expression in the mammary tissue and an increase in STC-mediated mammary gland involution. However, they failed to demonstrate any effect of the suppression of ovarian steroid secretion on milk yield, when applied during the first two-thirds of lactation (Delbecchi \& Lacasse, 2006). These data support the idea that the sensitivity of MECs to ovarian steroids, and specifically to $E$, evolves within the course of lactation. Apoptosis induced by $E_{2}$ in MECs seems to be more important in late lactation, in aging cells. In our study, the enhancement of apoptosis in MECs by $E_{2}$ is more efficient in early apoptotic cells which could be compared with senescent cells in the late-lactating mammary gland.

\section{Conclusions}

In this study, we showed that oestradiol induced slightly apoptosis on viable MEC and accelerated apoptosis on early apoptotic MEC after $48 \mathrm{~h}$ of treatment. This suggests that $E_{2}$ has a late differential effect that is dependent on the cells' viability. In lactating cows, the hormonal and cellular environment change over time and influence MEC status. More particularly, the decrease in cell survival factors during the course of lactation affects MEC viability. Therefore, the negative effect of $E_{2}$ on lactation persistency could be due to an enhancement of apoptotic processes in MECs.

The authors are grateful to American Journal Expert (Durham, NC, USA) for the language editing (certificate verification key: 35B8-0850-5CE5-1ADB-D90E). This research was co-supported by the French National Institute of Agricultural Science (INRA), the PHASE department.

\section{References}

Aker RM 2002 Lactation and the Mammary Gland. Ames: Blackwell Publishing

Athie F, Bachman KC, Head HH, Hayen MJ \& Wilcox CJ 1996 Estrogen administered at final milk removal accelerates involution of bovine mammary gland. Journal of Dairy Science 79 220-226

Berry SD, Jobst PM, Ellis SE, Howard RD, Capuco AV \& Akers RM 2003a Mammary epithelial proliferation and estrogen receptor alpha expression in prepubertal heifers: effects of ovariectomy and growth hormone. Journal of Dairy Science 86 2098-2105

Berry SD, Weber Nielsen MS, Sejrsen K, Pearson RE, Boyle PL \& Akers RM 2003 b Use of an immortalized bovine mammary epithelial cell line (MAC-T) to measure the mitogenic activity of extracts from heifer mammary tissue: effects of nutrition and ovariectomy. Domestic Animal Endocrinology 25 245-253

Capuco AV, Wood D, Baldwin R, Mcleod K \& Paape M 2001 Mammary cell number, proliferation, and apoptosis during a bovine lactation: relation to milk production and effect of bST. Journal of Dairy Science $\mathbf{8 4}$ 2177-2187

Clarke R 2000 Introduction and overview: sex steroids in the mammary gland. Journal of Mammary Gland Biology and neoplasia 5 245-50

Delbecchi L \& Lacasse P 2006 Suppression of estrous cycles in lactating cows has $\mathrm{n}$ effect on milk production. Journal of Dairy Science $\mathbf{8 9}$ 636-639

Delbecchi L, Miller M, Prud'homme C, Petitclerc D, Wagner GF \& Lacasse P 2005 17beta-oestradiol reduces milk synthesis and increases stanniocalcin gene expression in the mammary gland of lactating cows. Livestock Production Science 98 57-66

Desjardins C, Paape MJ \& Tucker HA 1968 Contribution of pregnancy, fetuses, fetal placentas and deciduomas to mammary gland and uterine development. Endocrinology 83 907-910

Forsyth IA 1986 Variation among species in the endocrine control of mammary growth and function: the roles of prolactin, growth hormone, and placental lactogen. Journal of Dairy Science 69 886-903

Hurley WL 1989 Mammary gland function during involution. Journal of Dairy Science 72 1637-1646

Huynh HT, Robitaille G \& Turner JD 1991 Establishment of bovine mammary epithelial cells (MAC-T): an in vitro model for bovine lactation. Experimental Cell Research 197 191-199

Jordan VC, Lewis JS, Osipo C \& Cheng D 2005 The apoptotic action of estrogen following exhaustive antihormonal therapy: a new clinical treatment strategy. Breast 14 624-630

Kolek O, Gajkowska B, Godlewski MM \& Motyl T 2003 Antiproliferative and apoptotic effect of TGF-beta 1 in bovine mammary epithelial BME-UV1 
cells. Comparative Biochemistry and Physiology Part C: Toxicology and Pharmacology 134 417-430

Lewis JS, Meeke K, Osipo C, Ross EA, Kidawi N, Li T, Bell E, Chandel NS \& Jordan VC 2005 Intrinsic mechanism of estradiol-induced apoptosis in breast cancer cells resistant to estrogen deprivation. Journal of the National Cancer Institute 97 1746-1759

Mollett TA, Erb RE, Monk EL \& Malven PV 1976 Changes in estrogen, progesterone, prolactin and lactation traits associated with injection of estradiol-1 7 beta and progesterone into lactating cows. Journal of Animal Science 42 655-663

Mor G, Kohen F, Garcia-Velasco J, Nilsen J, Brown W, Song J \& Naftolin F 2000 Regulation of fas ligand expression in breast cancer cells by estrogen: functional differences between estradiol and tamoxifen. Journal of Steroid Biochemistry and Molecular Biology. 73 185-194

Patel OV, Takenouchi N, Takahashi T, Hirako M, Sasaki N \& Domeki I 1999 Plasma oestrone and oestradiol concentrations throughout gestation in cattle: relationship to stage of gestation and fetal number. Research in Veterinary Science 66 129-33

Russo J, Yang X, Hu YF, Bove BA, Huang Y, Silva ID, Tahin Q, Wu Y, Higgy N, Zekri A \& Russo IH 1998 Biological and molecular basis of human breast cancer. Frontiers in Bioscience 3 D944-D960
Stefanon B, Colitti M, Gabai G, Knight CH \& Wilde CJ 2002 Mammary apoptosis and lactation persistency in dairy animals. Journal of Dairy Research 69 37-52

Tucker HA 2000 Hormones, mammary growth, and lactation: a 41-year perspective. Journal of Dairy Science $\mathbf{8 3} 874-884$

Wilde CJ \& Knight CH 1989 Metabolic adaptations in mammary gland during the declining phase of lactation. Journal of Dairy Science 72 1679-1692

Woodward TL, Beal WE \& Akers RM 1993 Cell interactions in initiation of mammary epithelial proliferation by oestradiol and progesterone in prepubertal heifers. Journal of Endocrinology $\mathbf{1 3 6}$ 149-157

Yart L, Finot L, Marnet PG \& Dessauge F 2012a Suppression of ovarian secretions before puberty strongly affects mammogenesis in the goat. Journal of Dairy Research 79 157-167

Yart L, Dessauge F, Finot L, Barbey S, Marnet PG \& Lollivier V 2012b Ovariectomy improves lactation persistency in dairy cows. Journal of Dairy Science 95 3794-3802

Zarzynska J, Gajewska M \& Motyl T 2005 Effects of hormones and growth factors on TGF-beta1 expression in bovine mammary epithelial cells. Journal of Dairy Research 72 39-48 